\title{
Uso de la documentación audiovisual en los informativos diarios de Canal Extremadura televisión
}

\author{
María Jesús BLANCO-IZQUIERDO \\ Canal Extremadura Televisión. Documentación \\ mariajesus.blanco@canalextremadura.es \\ Jorge CALDERA-SERRANO \\ Universidad de Extremadura. Departamento de Información y Comunicación. jcal- \\ ser@alcazaba.unex.es
}

Recibido: junio 2011

Aceptado: octubre 2011

Resumen: Se muestran los resultados del estudio realizado en Canal Extremadura Televisión en el cual se analiza la utilización de la información custodiada por el Departamento de Documentación. Se muestra por medio de un análisis minucioso tanto la temática del material requerido por los periodistas como el tiempo de emisión que ha sido extraído del material de archivo. Igualmente se analiza el formato de imágenes más solicitado así como para qué área geográfica (o cobertura territorial) ha sido utilizado preferentemente el material de archivo.

Palabras claves: Uso documental; Usuario; Documentación Audiovisual; Televisión; Canal Extremadura Televisión

\section{Use of audiovisual documentation in the daily reports of Canal Extre- madura TV}

\begin{abstract}
The results of a study conducted at Extremadura TV Channel are shown in this paper, discussing the use of information held by the Department of Documentation. It is shown through a careful analysis both the thematic material required by journalists and the ratio of broadcasted material that has been extracted from the archives. The format of images requested by journalists as well as their geographic coverage is also discussed has been used mainly archival material.
\end{abstract}

Keywords: Documentary use; User; Audiovisual Documentation; Television / Canal Extremadura TV

\section{INTRODUCCIÓN}

El ritmo de trabajo de un servicio de documentación de informativos de una televisión está marcado por las necesidades del redactor. La respuesta a la demanda 
de imágenes para la elaboración de un programa informativo diario debe ser rápida y precisa, siendo el nivel de exigencia del redactor cada vez más alto. Sin embargo, el servicio/departamento de documentación sigue sin ocupar un lugar importante en algunas empresas audiovisuales.

Aunque la labor realizada es importante, no siempre el trabajo es reconocido por las empresas audiovisuales aunque sí por los redactores que utilizan los servicios del departamento de documentación. Pero peor aún que la falta de reconocimiento es el desconocimiento de muchos implicados en la producción de información audiovisual de las fórmulas, métodos y posibilidades que ofrecen los servicios de documentación, lo que se traduce además de en el escaso reconocimiento indicado con anterioridad, en el desconocimiento de la necesidad de recursos humanos y económicos adecuados para llevar a cabo esta labor.

Con este trabajo se pretende mostrar la presencia y el uso de la documentación audiovisual en la gestación de los programas informativos diarios de Canal Extremadura Televisión, la cadena pública de Extremadura, a través de un análisis cuantitativo de la presencia de material de archivo en la elaboración de información de actualidad.

Para entender mejor algunos de los resultados obtenidos es necesario determinar que la cadena autonómica extremeña nace en 2005, y que el departamento de documentación aún se encuentra en fase de consolidación dentro del organigrama de la cadena.

\section{OBJETIVOS Y METODOLOGÍA DEL ESTUDIO}

Los objetivos marcados para este trabajo son los siguientes:

- Establecer en términos cuantitativos la presencia de la imagen de archivo en los informativos de la cadena.

- Determinar según los datos obtenidos la importancia del departamento de documentación dentro del informativo diario y, por ende, dentro de la empresa.

- Delimitar qué áreas temáticas, formatos y secciones informativas se nutren con mayor asiduidad de las imágenes de archivo.

Se ha analizado el programa informativo diario "Extremadura 20:30" de Canal Extremadura Televisión a lo largo de una semana de emisión, la comprendida entre el 19 y el 25 de abril de 2010, para identificar las imágenes de archivo emitidas en dicho programa y establecer así la presencia e importancia de la documentación audiovisual en la elaboración de este programa informativo.

Se ha recogido la siguiente información de cada una de las noticias:

Fecha de emisión.

Formato de la noticia: se define atendiendo a la forma de presentación de la información en el programa. Los posibles formatos que se han recogido en este trabajo son: breves, cebos, colas, colas + total, entradilla, totales y VTR. 
Sección: ámbito geográfico en el que se desarrolla la noticia, pudiendo ser este: local, regional, nacional o internacional.

Tema: asunto general del que trata la noticia. Se ha decido utilizar una serie de términos genéricos y amplios para clasificar todas las noticias del informativo. Las áreas temáticas se van a clasificar con los siguientes descriptores: Agricultura/Ganadería, Ciencia, Cultura, Deportes, Deportes-Fútbol, Economía, Educación, Empleo, Estado, Medio ambiente, Meteorología, Política, Sanidad, Sociedad, Sucesos y Transporte. Se ha decidido agrupar en un mismo descriptor "Agricultura" y "Ganadería", por tratarse de temas cercanos y que en muchos de los casos se tratan de forma conjunta al darse la información. Por otro lado, se ha decidido extraer el descriptor "Deportes-Fútbol" del más genérico "Deportes", dado que es un tema con suficiente presencia en los informativos como para tener una entidad propia. El término "Ciencia", sin embargo, tiene escasa presencia en los informativos, pero se ha decidido incluirlo para calificar una noticia en particular que no podía enmarcarse en ninguna otra categoría. Asimismo hay una categoría, "Otros", que se ha utilizado para calificar a una pieza del informativo que constituye un resumen en imágenes de los acontecimientos más importantes de la semana, y está compuesta, por tanto, por imágenes de temática variada.

Descripción de la noticia: breve reseña del contenido de la información.

Duración de la noticia.

Contiene archivo: Indicando en cada caso si la pieza informativa incluye alguna imagen con este origen o no.

Utilización de imágenes de archivo: Indicación de si se utiliza material de archivo de forma parcial o es el elemento que compone toda la noticia (montaje de archivo).

Duración de archivo: Duración de las imágenes de archivo dentro de la noticia expresada en minutos (") y segundos (").

Contiene rótulo "Archivo": Se alude aquí a si mediante un rótulo o un grafismo con la palabra "Archivo" o "Documentación" el redactor o el realizador indican que las imágenes utilizadas para elaborar la noticia son de archivo.

Posteriormente se ha procedido a la sistematización de los datos obtenidos y a su posterior análisis que se expresarán en los resultados del estudio. Sobre las imágenes que se han analizado, no se han incluido en el estudio las que se emiten en el plasma del plató mientras el presentador da entrada a la noticia, en primer lugar porque el número de veces en que estas aparecen no es muy significativa $\mathrm{y}$, en segundo lugar, por los elementos que distorsionan la percepción de la imagen y dificultan su identificación.

En ocasiones ha sido complicado establecer cuáles de las imágenes que componían la noticia eran o no de archivo, para ello se ha recurrido a la consulta de la base de datos documental de Canal Extremadura Televisión, Dalet, y sobre todo, a la ayuda y el asesoramiento de los documentalistas y redactores del canal. 


\section{RESULTADOS MÁS RELEVANTES}

Algunas de las noticias de actualidad más relevantes que se dieron durante la semana y que, por tanto, ocuparon mayor espacio en los diferentes informativos, fueron el caos aéreo en toda Europa provocado por la erupción del volcán islandés Eyjafjalla; el fallecimiento del presidente de honor del Comité Olímpico Internacional Juan Antonio Samaranch; la visita a Extremadura del rey Juan Carlos I con motivo del aniversario de la academia de la Guardia Civil de Mérida; y la aprobación por parte de la Asamblea de Extremadura del Pacto Social y Político de Reformas para la región. Estos bloques de acontecimientos semanales, no han utilizado en algunos casos documentación audiovisual, precisamente por su componente de máxima actualidad. Sin embargo, otros de estos temas, se han valido de la documentación para apoyar la actualidad de la noticia en hechos pasados y relacionados estrechamente con los del presente. Es por ello que no consideramos que la influencia de estas noticias de la semana pueda haber alterado los resultados finales del estudio, respecto a si el mismo se hubiera hecho otra semana cualquiera.

Para analizar el uso de la documentación audiovisual en el informativo se ha cuantificado tanto el número de noticias que contenían imágenes de archivo, como el tiempo que este tipo de imágenes ocupaban del total de imágenes emitidas. Lógicamente, los porcentajes de la medición del tiempo de archivo en las noticias, van a ser menores que la primera magnitud, pero aportan un elemento de mayor fiabilidad y que va a apoyar al primer dato.

Los datos se presentan en su conjunto, no programa por programa. En cualquier caso, no se han hallado grandes variaciones de datos para las mismas categorías entre unos programas y otros.

\subsection{NOTICIAS DEL INFORMATIVO CON MATERIAL DE ARCHIVO Y DURACIÓN DE DICHAS IMÁGENES SOBRE EL TOTAL DE LA EMISIÓN.}

Tabla I: Noticias con material de archivo y duración.

\begin{tabular}{|l|l|}
\hline Número total de noticias analizadas & 247 \\
\hline Número total de noticias con imágenes de archivo & 62 \\
\hline Porcentaje de noticias con imágenes de archivo & $25^{\prime} 1 \%$ \\
\hline Tiempo total de imágenes en noticias del informativo & $2 \mathrm{~h} 32^{\prime} 52^{\prime}{ }^{\prime}$ \\
\hline Tiempo total de imágenes de archivo en noticias del informativo & $24^{\prime}$ \\
\hline Porcentaje de tiempo de imágenes de archivo & $15^{\prime} 7 \%$ \\
\hline
\end{tabular}


Es destacable que en torno a $25 \%$ de las noticias contienen material de archivo, lo que se estima un dato significativo. Además supone que el tiempo total de imágenes de archivo es del $15^{\prime} 7 \%$ del total de las imágenes utilizadas.

\subsection{UTILIZACIÓN DEL MATERIAL DE ARCHIVO SEGÚN LA SECCIÓN O ÁREA GEOGRÁFICA.}

Tabla II: Uso material de archivo por Sección o área geográfica.

\begin{tabular}{|c|c|c|}
\hline $\begin{array}{l}\text { Número total de noticias de la sección } \\
\text { Internacional }\end{array}$ & 7 & $\begin{array}{l}\text { Archivo: } 1 \\
(14.28 \%)\end{array}$ \\
\hline $\begin{array}{l}\text { Tiempo total de imágenes de la sección } \\
\text { Internacional }\end{array}$ & $3^{\prime} 35^{\prime \prime}$ & $\begin{array}{l}\text { Archivo: } 57^{\prime \prime} \\
(26.51 \%)\end{array}$ \\
\hline $\begin{array}{l}\text { Número total de noticias de la sección } \\
\text { Nacional }\end{array}$ & 38 & $\begin{array}{l}\text { Archivo: } 10 \\
(26.31 \%)\end{array}$ \\
\hline $\begin{array}{l}\text { Tiempo total de imágenes de la sección } \\
\text { Nacional }\end{array}$ & $22^{\prime} 13^{\prime \prime}$ & $\begin{array}{l}\text { Archivo: 3' 44" } \\
(16,8 \%)\end{array}$ \\
\hline $\begin{array}{l}\text { Número total de noticias de la sección } \\
\text { Regional }\end{array}$ & 150 & Archivo: $45(30 \%)$ \\
\hline $\begin{array}{l}\text { Tiempo total de imágenes de la sección } \\
\text { Regional }\end{array}$ & $1 \mathrm{~h} 34^{\prime} 32^{\prime \prime}$ & $\begin{array}{l}\text { Archivo: } 17^{\prime} 31^{\prime \prime} \\
\left(18^{\prime} 53 \%\right)\end{array}$ \\
\hline $\begin{array}{l}\text { Número total de noticias de la sección } \\
\text { Local }\end{array}$ & 52 & $\begin{array}{l}\text { Archivo: } 6 \\
(11,54 \%)\end{array}$ \\
\hline $\begin{array}{l}\text { Tiempo total de imágenes de la sección } \\
\text { Local }\end{array}$ & $32^{\prime} 32^{\prime \prime}$ & $\begin{array}{l}\text { Archivo: } 1{ }^{\prime} 48^{\prime \prime} \\
(5,53 \%)\end{array}$ \\
\hline
\end{tabular}

Se observa que la presencia de la documentación audiovisual es más significativa en la sección de Regional, a priori la más importante y con más presencia en el informativo, donde alcanza el $30 \%$, y después en la de Nacional, con un $26 \%$ de presencia en el número de noticias. El dato de Internacional es aproximadamente la mitad, si bien, la presencia de esta sección en el informativo es poco significativa. Sin embargo, el porcentaje de la Sección Local, muy presente en el informativo baja respecto a las cifras anteriores.

Los porcentajes de tiempo de imágenes de archivo por Sección superan la media global, e incluso en el caso de Internacional superan el 26\%, si bien esta Sección no es muy significativa. En el caso de Local, la cifra es bastante baja. 


\subsection{UTILIZACIÓN DEL ARCHIVO AUDIOVISUAL ATENDIENDO A LA TEMÁTICA.}

Tabla III: Uso del archivo por temáticas / tiempo de archivo y porcentaje

\begin{tabular}{|c|c|c|}
\hline $\begin{array}{l}\text { Número total de noticias del tema Agricultura- } \\
\text { Ganadería }\end{array}$ & 12 & Archivo: 4 (33’33\%) \\
\hline $\begin{array}{l}\text { Tiempo total de imágenes del tema Agricultura- } \\
\text { Ganadería }\end{array}$ & $8^{\prime} 39^{\prime \prime}$ & Archivo: 52" (10.02) \\
\hline Número total de noticias del tema Ciencia & 1 & Archivo: $0(0 \%)$ \\
\hline Tiempo total de imágenes del tema Ciencia & $30^{\prime \prime}$ & Archivo: $0(0 \%)$ \\
\hline Número total de noticias del tema Cultura & 58 & Archivo: $5\left(8^{\prime} 62 \%\right)$ \\
\hline Tiempo total de imágenes del tema Cultura & $40^{\prime} 09^{\prime \prime}$ & $\begin{array}{l}\text { Archivo: 1'35”' } \\
\left(3{ }^{\prime} 94 \%\right)\end{array}$ \\
\hline Número total de noticias del tema Deportes & 24 & Archivo: $6(25 \%)$ \\
\hline Tiempo total de imágenes del tema Deportes & $12^{\prime} 27^{\prime \prime}$ & $\begin{array}{l}\text { Archivo: 2'44”' } \\
\left(21^{\prime} 95 \%\right)\end{array}$ \\
\hline $\begin{array}{l}\text { Número total de noticias del tema Deportes- } \\
\text { Fútbol }\end{array}$ & 26 & Archivo: 9 (34'61\%) \\
\hline $\begin{array}{l}\text { Tiempo total de imágenes del tema Deportes- } \\
\text { Fútbol }\end{array}$ & $13^{\prime} 10^{\prime \prime}$ & Archivo: 4' $\left(30{ }^{\prime} 38 \%\right)$ \\
\hline Número total de noticias del tema Economía & 6 & Archivo: $5(83 ’ 33 \%)$ \\
\hline Tiempo total de imágenes del tema Economía & $2^{\prime} 48^{\prime \prime}$ & $1 ’ 24 "(50 \%)$ \\
\hline Número total de noticias del tema Educación & 7 & $3\left(42^{\prime} 85 \%\right)$ \\
\hline Tiempo total de imágenes del tema Educación & $5^{\prime} 02^{\prime \prime}$ & $\begin{array}{l}\text { Archivo: 1'07' } \\
\left(22^{\prime} 18 \%\right)\end{array}$ \\
\hline Número total de noticias del tema Empleo & 8 & Archivo: $5\left(62{ }^{\prime} 5 \%\right)$ \\
\hline Tiempo total de imágenes del tema Empleo & $4^{\prime} 31^{\prime \prime}$ & 1'50" \\
\hline & 13 & $1\left(7^{\prime} 69 \%\right)$ \\
\hline Tiemp & $9^{\prime} 39^{\prime \prime}$ & Arcl \\
\hline $\begin{array}{l}\text { Número total de noticias del tema Medio am- } \\
\text { biente }\end{array}$ & 6 & Archivo: $2\left(333^{\prime} 33 \%\right)$ \\
\hline $\begin{array}{l}\text { Tiempo total de imágenes del tema Medio am- } \\
\text { biente }\end{array}$ & $3^{\prime} 40^{\prime \prime}$ & $\begin{array}{l}\text { Archivo: } 32^{\prime \prime} \\
\left(14^{\prime} 54 \%\right)\end{array}$ \\
\hline $\begin{array}{l}\text { Número total de noticias del tema del tema Me- } \\
\text { teorología }\end{array}$ & 3 & Archivo: $0(0 \%)$ \\
\hline Tiempo total de imágenes del tema Meteorología & $1{ }^{\prime} 06^{\prime \prime}$ & Archivo: $0(0 \%)$ \\
\hline Número total de noticias del tema Política & 24 & Archivo: $10\left(41^{\prime} 66 \%\right)$ \\
\hline Tiempo total de imágenes del tema Política & $16^{\prime} 31^{\prime \prime}$ & $\begin{array}{l}\text { Archivo: } 4^{\prime} 46^{\prime \prime} \\
\left(28^{\prime} 86 \%\right)\end{array}$ \\
\hline Número total de noticias del tema Sanidad & 3 & Archivo: $0(0 \%)$ \\
\hline Tiempo total de imágenes del tema Sanidad & $2 ' 19$ & Archivo: $0(0 \%)$ \\
\hline Número total de noticias del tema Sociedad & 30 & Archivo: 7 (23’33\%) \\
\hline
\end{tabular}




\begin{tabular}{|l|l|l|}
\hline Tiempo total de imágenes del tema Sociedad & $15^{\prime} 50^{\prime \prime}$ & $\begin{array}{l}\text { Archivo: 2'04' } \\
\left(134^{\prime} 05 \%\right)\end{array}$ \\
\hline Número total de noticias del tema Sucesos & 12 & Archivo: 3 (25\%) \\
\hline Tiempo total de imágenes del tema Sucesos & $5^{\prime} 47^{\prime \prime}$ & Archivo: 59' $(17 \%)$ \\
\hline Número total de noticias del tema Transporte & 13 & Archivo: 1 (7'69\%) \\
\hline Tiempo total de imágenes del tema Transporte & $9^{\prime} 25^{\prime \prime}$ & Archivo: 19' (3'36\%) \\
\hline Número total de noticias del tema Varios & 1 & Archivo. 1 (100\%) \\
\hline Tiempo total de imágenes del tema Varios & $1^{\prime} 19^{\prime \prime}$ & $\begin{array}{l}\text { Archivo: } 1 \text { '19” } \\
(100 \%)\end{array}$ \\
\hline
\end{tabular}

De los datos seleccionados por la variable Tema, observamos que las áreas en las que se emplea más documentación audiovisual de archivo son las de Economía (83’33\%), Empleo (62'5\%) y Educación (42’85\%), si bien estas categorías no son las más representadas dentro del informativo. En general, todas las categorías tienen porcentajes altos o, al menos, bastante representativos de noticias elaboradas con documentación audiovisual de archivo, es el caso de Agricultura/Ganadería (33'33\%), Deportes (25\%), Deportes-Fútbol (34'61\%), Medio ambiente (33'33\%), Política (41'66\%) -teniendo esta categoría mucha representación en el informativo- o sucesos $(25 \%)$.

Hay tres áreas en las que no se utiliza material de archivo: Ciencia, Sanidad y Meteorología. No obstante, la escasa cantidad de noticias que tratan estos temas nos hacen tomar este resultado como de escasa significación. Otra cuestión anómala, la representa la categoría de "Varios", con un $100 \%$ de presencia, puesto que se trata de un resumen semanal de las noticias más destacadas y por tanto elaboradas íntegramente con archivo. No obstante, lo hemos tenido en cuenta porque no deja de ser un exponente muy evidente del uso de la documentación audiovisual en los programas informativos. Las categorías menos representadas son Cultura (8'62\%) y Transporte (7'69), si bien hay que destacar que ocupan gran cantidad de noticias del informativo semanal debido a acontecimientos de actualidad candente y sin origen en el pasado, por tanto, menos susceptibles del uso de imágenes de archivo.

\subsection{UTILIZACIÓN DE DOCUMENTACIÓN AUDIOVISUAL SEGÚN EL FORMATO.}

Tabla IV: Uso del archivo según formato / tiempo y porcentaje

\begin{tabular}{|l|l|l|}
\hline $\begin{array}{l}\text { Número total de noticias del formato } \\
\text { Colas }\end{array}$ & 108 & $\begin{array}{l}\text { Archivo: } 24 \\
\text { (22'22\%) }\end{array}$ \\
\hline $\begin{array}{l}\text { Tiempo total de imágenes del formato } \\
\text { Colas }\end{array}$ & $38^{\prime} 17^{\prime \prime}$ & $\begin{array}{l}\text { Archivo: 6'57' } \\
\left(18^{\prime} 15 \%\right)\end{array}$ \\
\hline $\begin{array}{l}\text { Número total de noticias del formato } \\
\text { Colas + Total }\end{array}$ & 35 & Archivo: 6 (17'14\%) \\
\hline
\end{tabular}




\begin{tabular}{|c|c|c|}
\hline $\begin{array}{l}\text { Tiempo total de imágenes del formato } \\
\text { Colas + Total }\end{array}$ & $21^{\prime} 42^{\prime \prime}$ & $\begin{array}{l}\text { Archivo: 1'54" } \\
(8 ' 75 \%)\end{array}$ \\
\hline $\begin{array}{l}\text { Número total de noticias del formato } \\
\text { Breve }\end{array}$ & 20 & Archivo: $9(45 \%)$ \\
\hline $\begin{array}{l}\text { Tiempo total de imágenes del formato } \\
\text { Breve }\end{array}$ & $5^{\prime} 54^{\prime \prime}$ & $\begin{array}{l}\text { Archivo: 2'23”' } \\
\left(40^{\prime} 39 \%\right)\end{array}$ \\
\hline $\begin{array}{l}\text { Número total de noticias del formato } \\
\text { Cebo }\end{array}$ & 10 & Archivo: $3(30 \%)$ \\
\hline $\begin{array}{l}\text { Tiempo total de imágenes del formato } \\
\text { Cebo }\end{array}$ & $3^{\prime} 42^{\prime \prime}$ & $\begin{array}{l}\text { Archivo: } \\
\text { 1'36"'(43'24\%) }\end{array}$ \\
\hline $\begin{array}{l}\text { Número total de noticias del formato } \\
\text { VTR }\end{array}$ & 63 & $\begin{array}{l}\text { Archivo: } 19 \\
(28,57 \%)\end{array}$ \\
\hline $\begin{array}{l}\text { Tiempo total de imágenes del formato } \\
\text { VTR }\end{array}$ & $1 \mathrm{~h} 16^{\prime} 46^{\prime \prime}$ & $\begin{array}{l}\text { Archivo: 9'35' } \\
\left(12^{\prime} 48 \%\right)\end{array}$ \\
\hline $\begin{array}{l}\text { Número total de noticias del formato } \\
\text { Total o Entradilla }\end{array}$ & 9 & Archivo: $0(0 \%)$ \\
\hline $\begin{array}{l}\text { Tiempo total de imágenes del formato } \\
\text { Total o Entradilla }\end{array}$ & $4^{\prime} 50^{\prime \prime}$ & Archivo: $0(0 \%)$ \\
\hline
\end{tabular}

La presencia más elevada de noticias con uso de documentación audiovisual procedente del archivo se produce en la categoría de Breve (45\%), aunque también significativos son los porcentajes en las categorías Cebo (30\%) y VTR (28'57), esta categoría es la que se considera más importante, puesto que con este formato se desarrollan las noticias con más profundidad y a las que se les da más importancia. Más bajos son los porcentajes de los formatos Colas (22’22\%), Colas + Total $\left(17^{\prime} 14 \%\right)$ y sobre todo, de Total $(0 \%)$, esto se explica en tanto que es política de la empresa no conservar totales para archivo a no ser que sean de extrema importancia.

En cuanto al tiempo de imágenes de archivo, las cifras más elevadas las observamos en Breve (40’39\%) y Cebo (43’24\%). Para VTR y Colas presentan valores aceptables y en el caso de Totales y Colas + Total los porcentajes son bajos o nulos.

\subsection{RESULTADOS POR TIPO DE UTILIZACIÓN DE LAS IMÁGENES DE ARCHIVO}

Tabla V: Tipo de utilización de imágenes de archivo

\begin{tabular}{|l|l|}
\hline $\begin{array}{l}\text { Número total de noticias de archivo con Utilización parcial } \\
\text { de archivo }\end{array}$ & 29 \\
\hline $\begin{array}{l}\text { Porcentaje de noticias de archivo con Utilización parcial de } \\
\text { archivo }\end{array}$ & $46^{\prime} 77 \%$ \\
\hline
\end{tabular}




\begin{tabular}{|l|l|}
\hline $\begin{array}{l}\text { Tiempo total de imágenes de archivo con Utilización parcial } \\
\text { de archivo }\end{array}$ & $8^{\prime} 45^{\prime}$ ' \\
\hline $\begin{array}{l}\text { Porcentaje de tiempo de imágenes de archivo con Utilización } \\
\text { parcial de archivo }\end{array}$ & $36^{\prime} 46 \%$ \\
\hline Número total de noticias de archivo con Montaje de archivo & 33 \\
\hline Porcentaje de noticias de archivo con Montaje de archivo & $53^{\prime} 22^{\prime} \%$ \\
\hline Tiempo total de imágenes de archivo con Montaje de archivo & $15^{\prime} 15^{\prime} \%$ \\
\hline $\begin{array}{l}\text { Porcentaje de tiempo de imágenes de archivo con Montaje de } \\
\text { archivo }\end{array}$ & $63^{\prime} 54 \%$ \\
\hline
\end{tabular}

Estos datos se han tomado del total de noticias que utilizan archivo para su elaboración. Pese a que pudiera parecer lo contrario, las noticias que utilizan montaje de archivo son más del 53\% del total. Recordemos que se trata de noticias cuyas imágenes proceden exclusivamente del departamento de documentación. El resto de noticias con archivo son aquellas que mezclan imágenes de actualidad con documentación audiovisual.

En cuanto al tiempo que ocupan las noticias con montaje de archivo del total de imágenes del informativo, se trata de una cifra muy elevada, casi el $64 \%$.

\subsection{NOTICIAS QUE CONTIENEN IMÁGENES DE ARCHIVO CON INDICACIÓN EN RÓTULOS}

Tabla VI: Noticias con rotulación sobre su origen de archivo

\begin{tabular}{|l|l|}
\hline Número total de noticias de archivo con rótulo "Archivo" & 2 \\
\hline Porcentaje de noticias con rótulo "Archivo" & 3 '22\% \\
\hline
\end{tabular}

Este dato resulta revelador. Es muy bajo el porcentaje de noticias con imágenes de archivo en que el redactor ha acompañado a la información con el rótulo "Archivo" o "Documentación" para indicar la procedencia de las imágenes. Escasamente un $3 \%$ del total.

\section{CONCLUSIONES}

De este estudio finalmente podemos extraer las siguientes conclusiones de forma general:

- En todos los programas informativos analizados se usa documentación audiovisual. 
Es innegable, por tanto, la importancia que tiene el control, acceso y utilización de la documentación custodiada por el departamento de documentación audiovisual en Canal Extremadura para la elaboración del informativo y por ende para el funcionamiento de la empresa, puesto que el programa informativo se erige en la imagen principal de rigor y credibilidad que se quiere ofrecer de la cadena a los espectadores. Además su porcentaje de uso es representativo $(25 \%)$.

- La sección con más presencia en el informativo es la de Regional. La frecuencia de uso de material de archivo audiovisual en esta categoría es bastante representativa.

Este dato subraya el valor de la documentación audiovisual de archivo en el informativo, al nutrir a su sección más importante de forma considerable. Se observa que en el caso de Local la presencia de documentación es menor. Este dato puede deberse a que normalmente las noticias locales se refieren a acontecimientos de actualidad del mismo día o del día anterior, siendo por tanto más difícil que se refieran a hechos con un gran bagaje en el pasado; por otro lado los temas recurrentes y que precisan un mayor seguimiento se dan normalmente en las secciones de Regional y Nacional. Con lo que se concluye que la documentación nutre más abundantemente a las secciones informativas de mayor peso.

- Las temáticas que con mayor frecuencia utilizan el material del archivo audiovisual son las de Economía, Empleo y Educación. Política y Agricultura, también tiene una cantidad significativa de noticias con uso de material de archivo, junto con Deporte y Fútbol, en las que también se halla bien representada. Es decir, temas considerados con gran peso en el informativo, cuentan como fuentes habituales de información las que le proporciona el servicio de Documentación. En los casos de Economía, Empleo y Educación, las noticias están elaboradas en gran medida con imágenes de recurso: colegios, viviendas en construcción, bancos, gente trabajando, etc.

En el caso de la noticia del área Política sobre la aprobación del Pacto Social y Político de Extremadura, de gran importancia y calado en la política y sociedad extremeñas, tiene un amplio uso de material de archivo, haciéndose un análisis profundo de todos los acontecimientos que condujeron a dicho pacto. Se aprecia pues un componente de calidad en el uso de la documentación, que en este trabajo solo podemos esbozar, pero que puede ser estudiado en futuras investigaciones.

Es significativo sin embargo el caso de la sección Cultura, un tema de gran importancia y presencia en el informativo que contiene poco uso de material audiovisual procedente del archivo. En gran medida, estas noticias tratan temas de actualidad del día, como exposiciones o fiestas locales, que requieren para su confección poca o ninguna referencia a hechos pasados o apoyarse en imágenes de recurso. 
Casos como el de las áreas de Estado y Transporte, con una tasa menor de uso de material de archivo, cuentan con gran presencia en la semana estudiada, cada uno de estos temas se trata en 13 noticias. Mayoritariamente se centran en tres temas. En el caso del Transporte, en el caos aéreo y la paulatina apertura de los cielos europeos al tráfico. En el caso de Estado, en la visita del Rey a Extremadura y en los funerales de los soldados fallecidos en Haití, ambos temas de actualidad del día o los días en que se emitieron, por tanto, al igual que en el caso de la sección Local, el uso de material de archivo cuenta con menos sentido.

Hay tres áreas temáticas en las que no se ha usado material procedente del archivo audiovisual: Sanidad, Meteorología y Ciencia, pero su número hace que esto no resulte significativo.

Podemos concluir que las secciones con más peso e importancia del informativo tienen porcentajes altos o notablemente representativos.

- El uso de material del archivo audiovisual según el formato es equilibrado y representativo, salvo en el caso de los totales, en los que por política empresarial éstos no se guardan para reutilizar como material de archivo. En el resto se desmarca de la media el formato Breve, con un alto porcentaje, elaborado casi en su totalidad con material de archivo (montaje de archivo).

El formato de noticia que se considera más importante por su duración y el tratamiento de la información, el VTR, utiliza los recursos del archivo en casi el $30 \%$ del total. Lo cual nos indica que la documentación es un recurso que hay que tomar en cuenta como relevante para la información de calidad.

- Las veces en que una noticia con imágenes de archivo aparece rotulada con el grafismo "Documentación” o "Archivo" son mínimas.

Se concluye por tanto el escaso reconocimiento que se le concede a la documentación en la elaboración de la noticia, puesto que no se considera necesario identificar su origen de cara al espectador.

- Destacadísima la utilización de material procedente del archivo audiovisual en forma de montaje de archivo. Esto se traduce que existe un significativo porcentaje de noticias emitidas en el informativo de Canal Extremadura TV en el cual todo el material emitido procede del archivo audiovisual.

Más del 13\% de noticias están elaboradas en su totalidad con imágenes exclusivamente de archivo.

En resumen, y para finalizar, podemos señalar que el material de archivo en Canal Extremadura TV se emplea tanto como imagen de recurso como para contextualizar la información. Se abre aquí, como hemos señalado anteriormente, una nueva línea para la investigación del uso de documentación audiovisual en programas informativos, un estudio cualitativo que además de la función de la documentación en los informativos, estudiara los niveles de satisfacción del usuario que hace uso del servicio, si existe diferencia entre el uso de la documentación en 
informativos en días de diario e informativos en fin de semana o estudiar la procedencia del material audiovisual.

Para concluir, señalar la escasa presencia de Bibliografía en este trabajo derivado de los escasos estudios que se han realizado sobre dicha temática. No obstante se destaca la tesis doctoral de Teresa Aguirreazaldegui Berriozabal (1997), la cual analizaba el uso de la documentación en los informativos de las principales cadenas de televisión. No obstante, la metodología empleada es distinta a la empleada por la autora.

\section{RECONOCIMIENTOS}

Este trabajo fue financiado por la Consejería de Educación, Ciencia \& Tecnología de la Junta de Extremadura junto con el Fondo Social Europeo como ayuda a las labores de investigación del grupo GR10019.

\section{REFERENCIAS BIBLIOGRÁFICAS}

AGUIRREAZALDEGUI BERRIOZABAL, T. El uso de la documentación audiovisual en los programas informativos diarios de televisión. Bilbao: Universidad del País Vasco / Euskal Herriko Unibertsitatea, 1997.

CALDERA-SERRANO, J. ; NUÑO-MORAL, M.V. Diseño de una base de datos para televisión. Gijón, Trea, 2004.

CALDERA-SERRANO, J. ; ZAPICO-ALONSO, F. "Seen and heard: duality at the access point to television database", Aslib Proceedings: new information perspective, Vol. 58 (4). 2006, pp. 304-315.

HERNÁNDEZ PEREZ, Antonio. Documentación audiovisual: metodología para el análisis documental de la información periodística audiovisual. Madrid: Universidad Complutense, Facultad de Ciencias de la Información, Departamento de Periodismo III, 1992. 